\title{
POR UMA VIDA MELHOR NA MÍDIA: DISCURSO, AFORIZAÇÃO E POLÊMICA*
}

\author{
Roberto Leiser Baronas** \\ Maria Inês Pagliarini Cox***
}

Resumo: Neste artigo estuda-se, na perspectiva da análise de discurso, a polêmica em torno do livro didático de língua portuguesa Por uma vida melhor que teve lugar na mídia no primeiro semestre de 2011, gerando um numeroso arquivo de matérias jornalísticas sobre o tema. A polêmica se instaurou a partir de um conjunto de enunciados destacados do capitulo do livro, modificados segundo a ideologia do português único das Organizações Globo. $O$ corpus discursivo, constituído de enunciados recortados de matérias sobre o tema que circularam de modo impresso elou pela internet, foi examinado com base nos conceitos de destacabilidade e aforização (MAINGUENEAU, 2010, 2008), bem como nos conceitos de polêmica, interincompreensão, tradução e simulacro (MAINGUENEAU, 2005). Verifica-se se o destaque e a aforização potencializam a produção e a circulação de simulacros na esfera midiática.

Palavras-chave: Discurso midiático. Destacabilidade. Aforização. Polêmica. Simulacro.

* Uma versão modificada deste texto foi apresentada na forma de comunicação oral no IV Ciclo de Palestras em Análise de Discurso “Análise de Discurso: continuidades, calibragens, interfaces" no dia 04 de abril de 2013 na Universidade Federal de São Carlos - UFSCar. A programação do evento pode ser acessada no endereço <www.cicload.blogspot.com.br> ** UFSCar, Professor Adjunto IV, Doutor em Linguística e Língua Portuguesa. Email: baronas@ufscar.br.

*** UFMT, Professora Titular, Doutora em Educação. Email: minescox@hotmail.com.br 


\section{A IRRUPÇÃO DO ACONTECIMENTO: A (RE)CRIAÇÃO DO REAL}

Não faz muito tempo, acompanhamos uma ruidosa polêmica na mídia nacional em torno do livro didático de língua portuguesa Por uma vida melhor, distribuído gratuitamente pelo MEC aos estudantes da EJA (Educação de Jovens e Adultos). A polêmica começou no dia 17 de maio de 2011, quando, no programa matinal Bom Dia Brasil da Rede Globo, o jornalista Alexandre Garcia noticiou, assumindo um tom condenatório, que o MEC estava financiando livros didáticos que fomentavam o uso do português errado. De modo previsível, o jornalista recorreu à tópica do "antigamente" para ancorar sua argumentação, afirmando que, quando estava no primeiro ano do grupo escolar e falava errado, a professora o corrigia, preparando-o "para vencer na vida", pois tinha como óbvio que "A educação liberta e torna a vida melhor, nos livra da ignorância, que é a condenação à vida difícil. Quem for nivelado por baixo terá a vida nivelada por baixo". Disse, ainda, que, no Brasil, passa-se a mão nos erros por medo de constranger o outro e faz-se o mesmo com a língua, "aprova-se a palavra errada para não constranger" o aluno. Instalava-se aí um acontecimento discursivo que iria, apesar de sua curta trajetória na mídia, render uma farta safra de matérias assinadas por jornalistas ou por pessoas notáveis da esfera pública brasileira. Desde o início, a polêmica se instaurou a partir de um conjunto de enunciados destacados do capítulo do livro, modificados segundo a ideologia do português único das Organizações Globo e postos em circulação numa espécie de livro virtual, exibido no Jornal Nacional (ver figura 1, a seguir):

Incitados por esse factóide do livro didático, os mais diversos setores da elite do país (e a elite se tem como falante irretocável da Norma Padrão), escandalizados com fato de o MEC financiar, com dinheiro público, obras com "erros de português", começaram a se pronunciar sobre o episódio, sem ao menos se dar ao trabalho de ir ao livro didático para constatar, por conta própria, o que realmente seus autores afirmavam no texto original. Porém, os gramatiqueiros de plantão não contavam com a reação forte de professores e pesquisadores afinados com o discurso da linguística na lida com a língua na esfera escolar. A primeira providência desse grupo de vozes dissonantes em relação ao discurso da mídia foi ir ao livro mesmo e recuperar o cotexto extirpado pelos críticos mal-intencionados. 


\section{Figura 1 - Imagem exibida no Jornal Nacional para representar o livro Por uma vida melhor ${ }^{1}$}
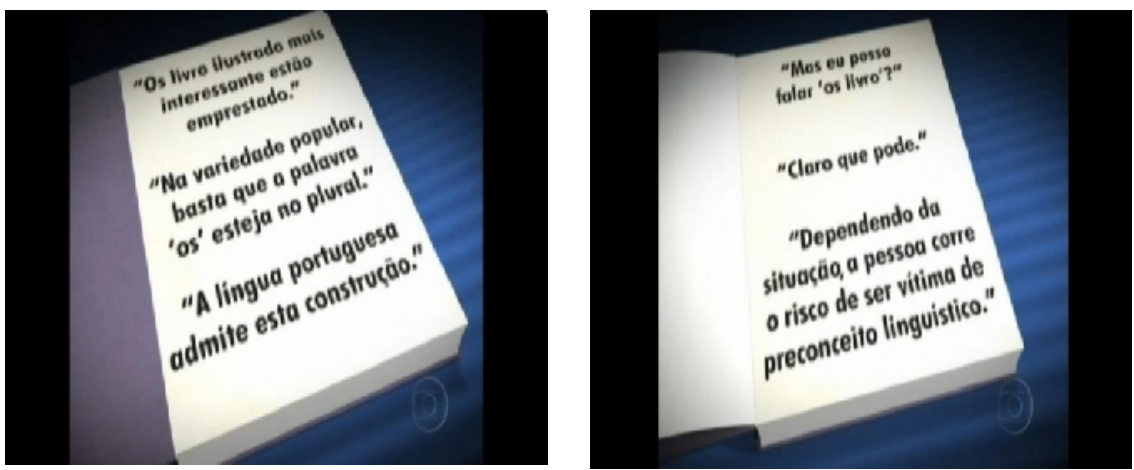

Os enunciados destacados fazem parte do primeiro capítulo, intitulado "Escrever é diferente de falar", mais exatamente, constam da seção "A concordância entre as palavras", em que a autora, seguindo uma orientação sociolinguística, trata da concordância nominal e verbal como um fenômeno variável e não categórico, sem deixar, todavia, de explicitar o valor social da norma culta, como podemos observar no excerto a seguir:

A concordância entre as palavras

A concordância entre as palavras é uma importante característica da linguagem escrita e oral. Ela é um dos princípios que ajudam na elaboração de orações com significado, porque mostra a relação existente entre as palavras. Verifique como isso funciona:

Alguns insetos provocam doenças, às vezes, fatais à população ribeirinha.

insetos (masculino, plural) $\leftarrow$ alguns (masculino, plural)

doenças (feminino, plural) $\leftarrow$ fatais (feminino, plural)

população (feminino, singular) $\leftarrow$ ribeirinha (feminino, singular)

\footnotetext{
1 Esta imagem foi retirada da reportagem exibida pelo Jornal Nacional. A reportagem completa, aos interessados, encontra-se disponível em: <http://www.youtube.com/watch?v=yxXQi2GjIKc>. Acesso em: 29 set. 2011.
} 
As palavras centrais (insetos, doenças, população) são acompanhadas por outras que esclarecem algo sobre elas. As palavras acompanhantes são escritas no mesmo gênero (masculino/feminino) e no mesmo número (singular/plural) que as palavras centrais. Essa relação ocorre na norma culta. Muitas vezes, na norma popular, a concordância acontece de maneira diferente. Veja:

Os livro ilustrado mais interessante estão emprestado. livro (masculino, singular) $\rightarrow$ os (masculino, plural) ilustrado (masculino, singular)
interessante (masculino, singular)
emprestado (masculino, singular)

Você acha que o autor dessa frase se refere a um livro ou a mais de um livro? Vejamos: O fato de haver a palavra os (plural) indica que se trata de mais de um livro. Na variedade popular, basta que esse primeiro termo esteja no plural para indicar mais de um referente. Reescrevendo a frase no padrão da norma culta, teremos:

Os livros ilustrados mais interessantes estão emprestados.

Você pode estar se perguntando: "Mas eu posso falar 'os livro?'." Claro que pode. Mas fique atento porque, dependendo da situação, você corre o risco de ser vítima de preconceito linguístico. Muita gente diz o que se deve e o que não se deve falar e escrever, tomando as regras estabelecidas para a norma culta como padrão de correção de todas as formas linguísticas. O falante, portanto, tem de ser capaz de usar a variante adequada da língua para cada ocasião.

(AGUIAR, C. A. et alii. Por uma vida melhor. Coleção "Viver, Aprender”. São Paulo: Global, 2011. p. 14-16).

A julgar por esse excerto, podemos constatar que os enunciadoresautores do livro buscam ensinar a Norma Padrão do português como uma de suas muitas normas e não como a única. Por essa razão, estabelece um contraste entre o funcionamento da concordância na norma culta e na norma popular, provavelmente aquela que os alunos da EJA dominam. Com essa comparação, equipara-se o status linguístico de uma e outra 
norma; não se trata, pois, de comparar o 'certo' com o 'errado', mas sim diferentes normas ("Muitas vezes, na norma popular, a concordância acontece de maneira diferente", dizem explicitamente os autores). Em resumo, eles apresentam a proposta didático-pedagógica de trabalho com concordância verbal e nominal interpelados pelo discurso linguístico, aqui referido como Discurso do Múltiplo (DM). O DM constituiu-se no solo da linguística moderna, nutrido principalmente pelas disciplinas e teorias que se recusam a extrair a língua de seus condicionantes sociais, históricos, culturais, políticos e ideológicos. Conforme o DM, o nome da língua é singular, mas sua existência é sempre plural. Assim, o português transforma-se em portugueses, diferentes entre si, todos eles linguística e estruturalmente perfeitos, mas avaliados e hierarquizados segundo a ordenação socioeconômica e política de seus falantes. Por assumir que a língua é um conjunto de variedades, o DM afasta-se do Discurso do Um (DU) que se enraíza na longeva tradição gramatical, reafirmando a ideologia purista, para a qual há apenas um português correto a ser conservado; o resto é caco, é lixo, é doença a ser curada pelos doutores da gramática que prescrevem, como antídoto, a Norma-Padrão, administrada em altas doses.

Nosso propósito neste artigo de pesquisa é estudar o destacamento e a aforização dos enunciados do livro didático como processos que potencializam a produção e a circulação de simulacros na esfera midiática, cenário em que grassa o DU. Além de "máquina de recortar e fazer circular enunciados" (MAINGUENAU, 2006), a mídia é também uma potente máquina de (trans)formar enunciados e produzir simulacros, segundo a(s) ideologia(s) dos grupos, organizações e instituições que os veiculam. Assim pensada, a mídia vai se patenteando muito mais como uma instância de circulação de sentidos e interpretações do que propriamente de circulação de fatos. Para explorar essa possível correlação entre aforização e produção de simulacros, vamos nos debruçar sobre um conjunto de matérias escritas veiculadas pela mídia impressa, televisa ou digital sobre o livro Por uma vida melhor. 


\section{MÍDIA: UMA MÁQUINA DE DESTACAR E AFORIZAR ENUNCIADOS}

É na companhia de Maingueneau $(2010,2008)$ que refletimos sobre uma prática corriqueira na comunicação midiática contemporânea - a prática de destacar enunciados e fazê-los circular em novas arenas. Maingueneau (2010, p. 9) afirma que "poucas pessoas hoje contestariam a ideia de que o texto constitui a única realidade empírica com a qual o linguista lida: unidades como a frase ou a palavra são necessariamente abstraídas de textos". E os textos, por sua vez, remetem-se a gêneros de discurso, que funcionam como quadros de referência para toda a comunicação pensável numa dada formação sócio-histórica. Maingueneau mobiliza o termo "gênero do discurso" para atividades como a participação de nascimento, o debate televisivo, a conversação, entre outras.

Todavia, a assunção de que o texto é a unidade básica de estudo não é imune a questionamentos quando o que se investiga são as práticas discursivas da mídia, esfera de comunicação em que abundam enunciados curtos, geralmente constituídos de uma única frase e que circulam fora do texto. Maingueneau (2010) chama essas pequenas frases de "enunciados destacados", incluindo slogans, máximas, provérbios, títulos de artigos da imprensa, intertítulos, citações célebres etc. $\mathrm{O}$ autor distingue duas classes de enunciados, segundo a natureza de seu "destacamento": a) $o$ constitutivo: trata-se do enunciado naturalmente independente de um contexto e cotexto (fórmulas sentenciosas, provérbios, slogans, divisas etc.) e b) o destacado por extração de um fragmento de texto, segundo a lógica de citação.

Essa extração não se exerce de maneira indiferenciada sobre todos os constituintes de um texto, pois, frequentemente, o enunciador sobreassevera alguns de seus fragmentos e os apresenta como destacáveis. A sobreasseveração é uma modulação enunciativa que habilita formalmente um fragmento como candidato a uma destextualização, ou seja, é

[...] uma operação de destaque do trecho que é operada em relação ao restante dos enunciados, por meio de marcadores diversos: de ordem aspectual (genericidade), tipográfica (posição de destaque dentro uma unidade textual), prosódica (insistência), sintática 
(construção de uma forma pregnante), semântica (recurso aos tropos), lexical (utilização de conectores de reformulação)... (MAINGUENEAU, 2010, p. 11)

Num trabalho diligente de afinação dos conceitos, Maingueneau (2008, p. 92) distingue a sobreasseveração da aforização, uma vez que cada uma delas funciona segundo uma lógica própria. Enquanto a sobreasseveração se dá no texto, pela acentuação de uma sequência contra um fundo textual, a aforização extrai os enunciados do texto e põe-nos a circular fora dele, em outras cenas de enunciação. Assim, a aforização ressignifica a citação, uma vez que não se trata mais de representar a voz do Outro, mas sim de apresentar a Verdade ou a Lei, produzida alhures a partir do contato com uma Fonte Transcendente, como se elas mesmas se apresentassem.

Segundo Maingueneau, o enunciado fonte e o enunciado destacado divergem quanto a seu estatuto pragmático. Os enunciados destacados estão sujeitos a um regime de enunciação denominado "enunciação aforizante". Entre uma "aforização" e um texto, as diferenças não são apenas de tamanho, de forma, de sistematicidade linguística, mas sim de ordem enunciativa. $\mathrm{O}$ esquema a seguir representa as duas ordens enunciativas propostas pelo autor:

Figura 2 - Esquema vetorial das ordens enunciativas

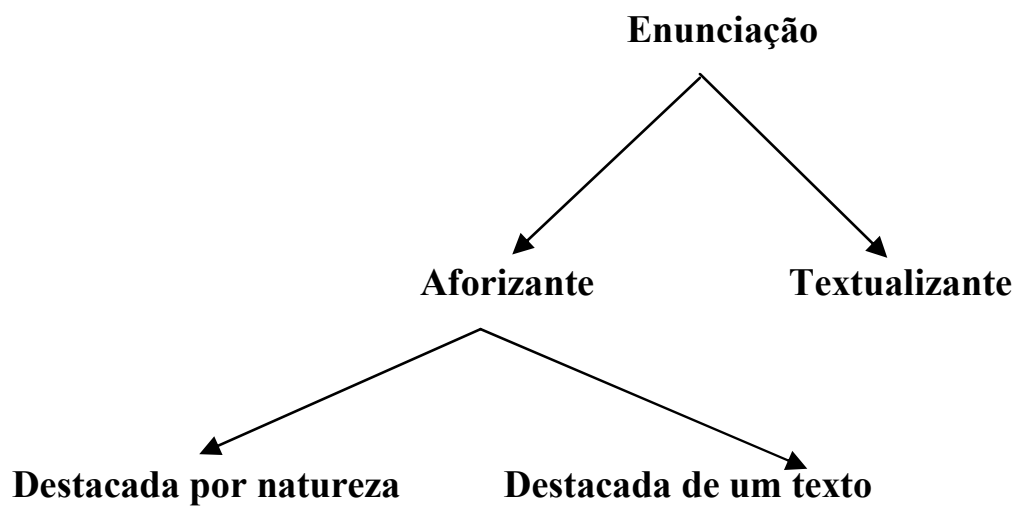

Fonte: Maingueneau, 2010, p. 13 
Como podemos visualizar nesse esquema, Maingueneau (2010, p. 13-15) propõe duas ordens de enunciação: a enunciação textualizante e a enunciação aforizante. A enunciação aforizante, por sua vez, se organiza em enunciação aforizante destacada por natureza e enunciação aforizante destacada de um texto. Elas se diferenciam da enunciação textualizante em vários aspectos. Enquanto a enunciação textualizante define posições correlativas de produção e recepção e papéis específicos para o enunciador e o enunciatário negociados em conformidade com a cena genérica, a enunciação aforizante prescinde de posições correlativas, definindo uma cena onde o locutor, um Sujeito jurídico e moral, fala a uma espécie de auditório universal. Enquanto a enunciação textualizante envolve jogos de linguagem de diversas ordens como argumentar, narrar, perguntar, responder etc., a aforizante pretende apresentar o pensamento do locutor como a verdade soberana, para além dos jogos da linguagem. Enquanto a enunciação textualizante estratifica os planos enunciativos, a aforizante tende à homogeneização. Se, por um lado, a enunciação textualizante varia segundo os gêneros, suportes e modos de circulação, a aforizante, por outro, não é afetada por tais condicionantes. Enquanto a enunciação textualizante ultrapassa a dimensão propriamente verbal, a aforizante pretende ser pura fala. Se a enunciação textualizante desfavorece a memorização, a aforizante "implica a utopia de uma fala viva sempre disponível" e repetível. Por meio da aforização, o locutor busca se colocar além dos limites, condicionantes e restrições específicos de um determinado gênero do discurso:

$\mathrm{O}$ « aforizador » assume o ethos do locutor que fala do alto, de um indivíduo em contato com uma Fonte transcendente. (...) Trata-se, fundamentalmente de fazer coincidir sujeito da enunciação e Sujeito no sentido jurídico e moral: alguém se coloca como responsável, afirma valores e princípios perante o mundo, dirige-se a uma comunidade que está além dos alocutários empíricos que são seus destinatários. (MAINGUENEAU, 2010, p. 14-15).

Desse modo, quando se extrai um fragmento de texto para fazer uma aforização, um título de uma matéria na imprensa, por exemplo, converte- 
se ipso facto seu locutor original em aforizador. E o aforizador, como Sujeito, "diz o que é, não no instante, mas na duração atemporal do valor" (MAINGUENEAU, 2010, p. 14-15).

Se compararmos os enunciados do livro virtual, destacados e aforizados de seu contexto e cotexto (figura 1), com os enunciados sublinhados no excerto extraído do texto fonte, observaremos as seguintes alterações $^{2}$ :

1: Os livro ilustrado mais interessante estão emprestado. (destacado); Os livro ilustrado mais interessante estão emprestado. (livro fonte);

2: Na variedade popular, basta que a palavra 'os' esteja no plural. (destacado);

$\mathrm{Na}$ variedade popular, basta que ESSE PRIMEIRO TERMO esteja no plural para indicar mais de um referente. (livro fonte);

3: A língua portuguesa admite essa construção. (enunciado criado);

4: Mas eu posso falar "os livro?" (destacado);

Mas eu posso falar "os livro?" (livro fonte);

5: Claro que pode. (destacado);

Claro que pode. (livro fonte);

6: Dependendo da situação, a pessoa corre o risco de ser vítima de preconceito linguístico (destacado);

Mas fique atento porque, dependendo da situação, VOCÊ corre o risco de ser vítima de preconceito linguístico. (livro fonte).

O enunciado 1 destacado é formalmente idêntico ao enunciado do texto fonte, porém, apartado do cotexto, ele deixa de ser o exemplo de uma comparação entre a norma culta e a norma popular quanto ao funcionamento da concordância nominal. $\mathrm{O}$ enunciado 2 destacado não coincide com aquele do texto fonte, pois além de substituir a locução anafórica "esse primeiro termo" por "a palavra "os", corta a parte final do

\footnotetext{
${ }^{2} \mathrm{O}$ trecho em CAIXA ALTA foi substituído no enunciado destacado e aquele em itálico, suprimido.
} 
período (em itálico no texto fonte) que explica como falantes da norma popular expressam linguisticamente a noção de número (mais de um referente) na locução nominal, ou seja, eles o fazem flexionando apenas o artigo. $\mathrm{O}$ enunciado 3 foi inteiramente criado pela reportagem. Ele altera radicalmente o posicionamento discursivo dos enunciadores-autores, uma vez que absolutiza, como própria da língua portuguesa, uma forma gramatical apresentada como relativa tão somente à norma popular. Não sem razão, o enunciado 3, inexistente no texto fonte, foi o principal motivador da ira de fieis e seguidores do DU. Os enunciados 4 e 5 destacados, correspondentes ao diálogo imaginário travado entre professor e aluno, são formalmente iguais aos do texto fonte. Finalmente, no enunciado 6 destacado, a oração adversativa que inicia o período (em itálico no texto-fonte) é suprimida e o pronome pessoal "você" é substituído por "a pessoa", anulando a dêixis mediante a qual o professor se dirige diretamente ao aluno suposto que fez a pergunta "Mas eu posso falar 'os livro'?". A substituição de "você" por “a pessoa” e a supressão da oração adversativa que introduz uma ideia contrária à que veio antes (Claro que pode), interpelando o aluno com quem dialoga a ficar atento, pois não é em qualquer situação que a forma 'os livro' é aceita, fazem parte do mesmo trajeto interpretativo, irrigado pelo DU, que busca responsabilizar os enunciadores-autores pela generalização insana do uso de um suposto "erro de português", autorizando-o não mais num determinado contexto, mas em todos os contextos.

É tão somente a partir desse conjunto de enunciados destacados e aforizados que o livro didático passa a circular na mídia, fazendo proliferar matérias jornalísticas e entrevistas ao vivo com especialistas das Letras, além de incitar a doxa a se manifestar ruidosamente. Considerando que a fonte não é uma matéria divulgada pela grande mídia, conhecida e disponível ao público, mas um livro didático, poucos dos que se arvoram a opinar sobre o caso, engrossando o arquivo de enunciados sobre ele, têm o cuidado de buscar o texto original para conferir o que efetivamente ele diz. Apesar de o capítulo do livro ter sido disponibilizado para consulta pela internet, a maioria das matérias sobre ele se teceu com base apenas no livro virtual exibido pela Rede Globo. Trata-se, pois, de um caso exemplar de 
aforização forte em que os enunciados destacados ganham vida própria, esquecida a sua origem, contexto e cotexto.

Esse trajeto interpretativo demonstra que não estamos diante de um mero trabalho de citação, em que os enunciados destacados são colocados a circular em outros textos, demarcados por alguma sinalização de distanciamento, como: aspas, itálicos, introdução por um verbo dicendi seguido de "que", que torna inconfundíveis os limites entre o Mesmo e o Outro. Há, sim, um trabalho de aforização que corrobora o percurso deôntico interpretativo numa dada direção de sentido, qual seja, o de jogar as asseverações do posicionamento da grande mídia para a responsabilidade da autoria do livro e, por sua vez, para a responsabilidade do MEC, que o abona a ponto de incluí-lo no PNLD. Ainda que isso possa ser dito também a respeito de outros tipos de citação, quando o 'citador' marca, de alguma maneira, seu distanciamento em relação àquilo que cita, no caso da aforização, vários apagamentos comprometem a compreensão "real" do acontecimento: o apagamento do cotexto e contexto em que os enunciados foram produzidos, a inexistência de prévia leitura do material pelos leitores do jornal, o silenciamento da voz de quem de fato participou da elaboração do material e a não explicitação das fronteiras entre os elementos alterados e criados pelos jornalistas e os elementos do próprio livro. Por sua vez, o enunciador jornalista se constitui num aforizador que se sobrepõe tanto ao seu leitor quanto ao locutor-enunciador cuja fala recorta e aforiza. Afinal, é como um Sujeito pleno de direito que o aforizador pronuncia a Verdade sobre a língua - existe apenas um português correto - para um auditório universal, Verdade com a qual os jornalistas e as instituições que eles representam se alinham. Destarte, a aforização realiza um trabalho de direcionamento de sentidos, de constituição de subjetividades em que, sem que se dê conta, o leitor é levado a aderir à interpretação do enunciador jornalista e, por extensão, ao posicionamento discursivo do veículo midiático em nome de que fala-escreve e significa. Um aforizador é uma espécie de entidade suprema, ele afirma valores e princípios intemporais para além e aquém das circunstâncias imediatas e dos alocutários empíricos. Segundo Maingueneau (2010, p. 15), “A descontextualização das aforizações é acompanhada por uma opacificação de seu sentido, que 
exige um trabalho interpretativo". Assim, acompanhar, na arena midiática, a polêmica instaurada pelo conjunto de enunciados destacados e aforizados do livro Por uma vida melhor é acompanhar o trabalho de interpretação realizado por uma legião de seguidores que se compraz em reiterar a Verdade, essencial ao DU, e, consequentemente, em produzir simulacros do DM.

\section{MÍDIA: UMA MÁQUINA DE (RE)PRODUZIR SIMULACROS}

Subsumimos aqui a tese do primado do interdiscurso, segundo a qual na gênese de um discurso sempre se encontram outros discursos ou o discurso do Outro. Operacionalizada metodologicamente por meio da tríade conceitual - universo discursivo (todos os discursos de uma dada formação sócio-histórica), campo discursivo (os discursos que se delimitam reciprocamente numa região específica do universo discursivo) e espaço discursivo (discursos que o analista recorta para estudo, por vislumbrá-los como inextricavelmente ligados num dado campo) -, a tese do interdiscurso "faz aparecer a interação semântica entre os discursos como um processo de tradução, de interincompreensão regrada" (MAINGUENEAU, 2005, p. 22). Um espaço discursivo delimitado pressupõe a coexistência de um Mesmo e de um Outro que se opõem, constituem-se, delimitam-se, replicam-se etc. Isso quer dizer que enunciar de acordo com as regras de um dado discurso implica necessariamente não compreender os enunciados do Outro. A interincompreensão significa mais do que uma simples troca entre discursos. Trata-se de um processo de interpretação recíproca, em que cada formação discursiva somente "compreenderá" o seu Outro de acordo com seu próprio registro que inclui "os semas 'positivos', reivindicados" e “os semas 'negativos', rejeitados”. Sobre os enunciados do Outro, projetam-se os semas negativos, pois "para constituir e preservar sua identidade no espaço discursivo, o discurso não pode haver-se com o Outro como tal, mas somente com o simulacro que constrói dele". (MAINGUENEAU, 2005, p. 103).

$\mathrm{O}$ autor se refere à interpretação que um discurso realiza de seu Outro como um processo de tradução. Logicamente ele não está pensando 
em tradução de uma língua para outra, mas sim de um discurso para outro com base nas regras da formação discursiva em que o "eu" se inscreve. Afinal, a opacidade semântica não é um apanágio de línguas distintas, pois, dentro de uma mesma língua, podem ocorrer zonas de interincompreensão que o senso comum tão precisamente designa como "diálogo de surdos". Para explicitar esse processo de tradução interdiscursiva, Maingueneau (2005, p. 103) distingue, em relação ao espaço discursivo, o discursoagente - discurso tradutor - do discurso-paciente - discurso traduzido. Nesse espaço, o discurso-agente traduz o discurso-paciente por meio dos semas que rejeita. Assim, a relação entre o discurso agente e o discurso paciente "se dá sempre sob a forma do simulacro' que dele constrói" (MAINGUENEAU, 2005, p. 22). É esse processo de tradução-simulacro que permite que os discursos preservem-se na ilusão do fechamento semântico. Por estarem cerceados por seu registro, por suas próprias restrições semânticas, por seus lugares de dizer, não podem "compreender" os sentidos outros que vão contra a sua própria constituição, a não ser negativamente.

O conceito de interincompreensão também é imprescindível para o tratamento da polêmica. Apesar de ser comumente entendida como uma forma de conflito "perceptível" na superfície linguística, marcada por controvérsias explícitas, a polêmica pode presentificar-se na forma de um dialogismo constitutivo. Daí Maingueneau (2005, p. 112) distinguir dois níveis: o nível dialógico (heterogeneidade constitutiva) e o propriamente polêmico (heterogeneidade mostrada). No nível dialógico, subsume-se que os discursos se relacionam constantemente, imbricam-se sem que haja citação aparente, ou seja, heterogeneidade mostrada na superfície linguística. Já no nível propriamente polêmico, subsume-se que a heterogeneidade, as dissensões, as oposições, as controvérsias são visíveis na superfície linguística. Um discurso envolvido em uma polêmica poderá se referir ao seu Outro de forma clara, usando expressões variadas: agressivas, mal-intencionadas, derrisórias, irônicas, intrigantes, ameaçadoras etc., mas todas essas expressões serão desferidas pelo Mesmo a partir de um simulacro do Outro. A polêmica é uma "espécie de homeopatia pervertida: ela introduz o Outro em seu recinto para melhor 
conjurar sua ameaça, mas esse Outro só entra anulado enquanto tal, simulacro" (MAINGUENEAU, 2005, p. 113). Assim concebida, a polêmica deixa de ser pensada como um conflito originário do exterior que se agrega a um discurso por direito autossuficiente e passa a ser pensada com inerente às suas condições de possibilidade. Em síntese, "a identidade de um discurso coincide com a rede de interincompreensão na qual é capturada" (MAINGUENEAU, 2005, p. 22).

Certamente, nem todos os temas suscitarão conflitos abertos entre formações discursivas que se relacionam em um dado espaço. Retomando a tese foucaultiana de que "o enunciado é raro", Maingueneau (2005, p. 113) afirma que "a lista dos assuntos efetivamente debatidos é muito limitada, e mesmo pouco variada, a polêmica indo e voltando em torno de poucos pontos". Essa afirmação se aplica perfeitamente à polêmica sobre o livro didático aqui estudada. Novamente vemos a mídia, interpelada pelo DU, sair em praça pública para defender a existência de apenas uma norma linguística correta, polemizando com o DM que admite uma pluralidade de normas. Esse é o ponto-chave da dissensão e contenda entre o DU e o DM. E é sempre sobre esse tema que vemos a mídia se pronunciar sobre a língua. Não foi diferente no momento em que acompanhamos o ruidoso acontecimento discursivo gerado pelo projeto de lei 1676/1999 que pretendia coibir/regular o uso de estrangeirismos no Brasil. A polêmica entre o DU e o DM reenvia, pois, à "incompatibilidade de dois universos semânticos, pela qual nenhum reconhece a maneira que o Outro tem de estar de acordo com a Lei" (MAINGUENEAU, 2005, p. 117). A Lei, uma espécie de Lenda ou Tesouro comum, é, no caso da polêmica entre o DU e o DM, a Norma-Padrão que, segundo Rey (2002, p. 118), funciona como:

[...] um modelo, um arquétipo, uma idéia platônica. Esse arquétipo é progressivamente desprendido da vontade de um legislador para se fundar ficticiamente numa norma constituída, que bastará observar para descobrir "objetivamente", para instituir um modelo de uso "sadio" e ter o direito de "curar" os desvios, as diferenças.

Sobre a Lenda da Norma-Padrão, "cada discurso constrói a sua própria Lenda". O DU a elege como a única norma gramatical desejável, 
como o modelo a ser seguido, embora nunca a realize plenamente. Porém, o irrealizado da Norma-Padrão é sempre silenciado pelo DU. Já DM interpreta a Norma-Padrão como a norma ideal entre as normas reais, essas últimas todas gramaticalmente possíveis e aceitáveis, dependendo da situação de enunciação. As normas reais, mesmo as ditas cultas, não cessam de mostrar o irrealizado da Norma-Padrão.

Explorando o destaque e a aforização dos enunciados do livro didático realizados pela mídia em relação ao texto original, à luz do conceito de polêmica (e seus correlatos: interincompreensão, tradução e simulacro), constatamos que as restrições semânticas do DU - o discursoagente - presidem a filtragem do enunciados destacados e aforizados. Como afirma Maingueneau (2005, p. 115), "O método mais simples para não colocar-se em contradição com o corpus canônico é efetuar uma triagem, convocar os fragmentos que vão no sentido de quem escreve e deixar na sombra os que vão no sentido de seu Outro". Se observarmos atentamente o texto da seção do livro didático de onde foram destacados e aforizados os enunciados que compõem o livro virtual, notamos que o primeiro enunciado "Os livro ilustrado mais interessante estão emprestado" só aparece efetivamente depois de uma explicação e exemplificação pormenorizada da concordância nominal segundo a norma culta. É imediatamente antecedido da frase "Muitas vezes, na norma popular, a concordância acontece de maneira diferente" que relativiza o escopo de aplicação da regra de concordância nominal e seguido de uma explanação de como a norma popular expressa o número plural e de uma demonstração de como ficaria tal frase se reescrita de acordo com a norma culta: "Os livros ilustrados mais interessantes estão emprestados".

Além de a operação de destaque e aforização ser, ela mesma, uma tradução-simulacro, ela também fomenta uma produção pletórica de simulacros, na medida em que põe em circulação na mídia apenas os enunciados destacados e aforizados que afrontam um dogma gramatical segundo o senso comum. Inúmeros jornalistas e articulistas da grande mídia saíram na cena pública para dar a "sua" versão dos fatos, sempre a partir da tradução-simulacro embutida e disseminada pelo destaque primeiro, realizado pelo jornalismo global. As matérias circularam com nomes como: 
1. "Os adversários do bom português." (Veja, 25/05/11).

2. "O assassinato da língua portuguesa." (ISTO É, 20/05/11).

3. “Fale errado, está certo." (Folha de S. Paulo, 20/05/11).

4. "A consagração da ignorância." (ISTO É, 20/05/11).

5. "Livros pra inguinorantes." (Jornal do Brasil, 15/05/11).

6. "Inguinorança." (Folha de S. Paulo, 15/05/11).

7. “A çituassão está gramática!’(O Globo, 22/05/11).

Todos esses nomes subsumem, como pré-construído, que há uma língua portuguesa correta, absoluta, incontestável. E é esse pré-construído que leva o enunciador-articulista de cada matéria a recorrer a palavras com semas negativos para nomear os enunciadores-autores do livro didático e/ou a tese sociolinguística que embasa a proposta didático-pedagógica. Se há um "bom português", quem não o reconhece é seu "adversário", seu “assassino". Vários dos nomes aí listados revelam uma aliança do DU com o discurso iluminista, que reparte o mundo cultural em 'civilização' e 'barbárie', respectiva e maniqueístamente significados como 'o bem' e 'o mal' em termos absolutos, virando as costas para todos os conhecimentos produzidos pelas ciências humanas, principalmente a antropologia e a linguística. O bom português - a Norma-Padrão - é a língua da civilização, o resto é barbárie, e, como tal, não pode estar na escola que é lugar de iluminar/civilizar as almas bárbaras, o que justifica a recorrência aos termos "ignorância/ignorantes", seja em tom sério como "A consagração da ignorância", seja em tom derrisório como "Livros pra inguinorantes" e "Inguinorança", em que a cacografia é usada para carregar nas tintas da crítica e da condenação da postura relativista adotada pelo livro didático em relação às normas gramaticais. Um vez mais vemos a mídia, inadvertidamente, colocar no mesmo saco a ortografia de uma língua (unificada por decreto) e sua(s) gramática(s), o que também nos autorizaria a devolver-lhes a pecha de "ignorantes", mas essa discussão não vem ao caso neste momento. Além do recurso à cacografia, o nome "A çituassão está gramática!" explora também o trocadilho dramática/gramática, com o propósito de reforçar a visão apocalíptica - de morte iminente da língua portuguesa - daqueles que professam o DU. Nessa mesma linha das figuras 
de linguagem, também o paradoxo é explorado em "Fale errado, está certo", proposição que desafia a opinião compartilhada, o senso comum, de que não está certo falar errado.

Do mesmo modo, a filtragem pela peneira semântica do DU ocorre na nomeação dos enunciadores-autores do livro didático e, por extensão, dos linguistas, que eles representam:

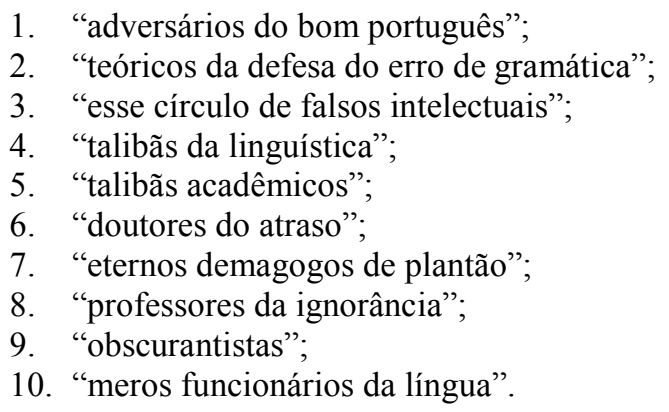

Todas as designações contidas nessa lista incluem um sema de desaprovação em relação àqueles enunciadores que falam interpelados pelo DM. Para aqueles enunciadores que falam interpelados pelo DU, para quem o português é único, quem diz outra coisa é um "adversário", um "defensor do erro", um "falso intelectual", um "demagogo", designações que desabonam quem enuncia em nome da 'ciência' linguística como embusteiro, impostor. Já as designações antitéticas e sardônicas "doutores do atraso", "professores da ignorância" e "obscurantistas" retomam o discurso das Luzes para desqualificar os linguistas, pois, apesar de 'doutores' e 'professores' (quer dizer, apesar de sábios), não ensinam a boa língua, a língua correta, e sim cultivam a fala do populacho que é sinônimo de "atraso", "ignorância" e "obscurantismo". Também o termo "talibãs", que figura nas locuções "talibãs da linguística" e "talibãs acadêmicos", tem o poder de evocar uma carga semântica altamente negativa, uma vez que é inseparável das ideias de fundamentalismo religioso, autoritarismo, radicalismo e terrorismo. Já a nomeação como "meros funcionários da língua", partindo do pré-construído da Norma-Padrão, lembra que a transgressão é coisa para artistas e não para linguistas, professores e autores 
de livros didáticos, esses "têm que aderir a ela", sem quaisquer gestos de insurreição. Os semas negativos também são abundantes nas expressões por meio de que os enunciadores-articulistas se referem à proposta didáticopedagógica balizada pela tese sociolinguística de que uma língua é um conjunto heterogêneo de variedades linguísticas, tese que solapa o absolutismo do princípio de correção em defesa do qual se pronunciam:

1. "tese absurda";

2. "esse despautério";

3. "essa aberração";

4. "estupidez";

5. "tolice";

6. "desvarios dos talibãs acadêmicos";

7. "uma barbaridade";

8. "a consagração da ignorância";

9. "apologia da mediocridade";

10. "um material que emburrece em vez de instruir";

11. "uma pregação obtusa";

12. "essa burrice";

13. "inversão de valores";

14. "licenciosidade linguística";

15. "apologia do erro";

16. "a demagogia do oprimido";

17. "uma pregação demagógica";

18. "um desserviço";

19. "um desserviço aos jovens de uma nação iletrada sedenta de conhecimentos";

20. "um desastre";

21. "o assassinato da língua";

22. "crime linguístico";

23. "crime contra nossos jovens";

24. "caso flagrante de gramaticofobia";

25. "lixo acadêmico travestido de vanguarda cultural";

26. "visão mesquinha".

Como podemos observar pela lista anterior, os sintagmas nominais que retomam a tese-posição favorável à heterogeneidade linguística, assumida pelos enunciadores-autores do livro didático, reverberam, todos eles, uma aura negativa. Tomados de diferentes campos conceituais, 
servem ao gesto interpretativo único de desqualificar, depreciar, reprovar, desacreditar o Outro. O campo da razão/desrazão fornece os termos "absurdo", “despautério", “aberração", “estupidez", "tolice” e “desvario", para avaliar a tese como contrária ao bom senso, como destituída de racionalidade e discernimento, como um ato de insanidade mental, loucura mesmo. Complementarmente, o campo do saber/ignorância disponibiliza os termos "barbaridade", "ignorância", "mediocridade", "burrice" e "obtuso", para, reiterando o discurso iluminista, reprovar a tese, por ela não incentivar o progresso intelectual e, por consequência, social dos alunos. $\mathrm{O}$ campo da moral contribui com os termos "inversão de valores", "licenciosidade", "apologia do erro", "demagogia" e "desserviço", para desqualificar o livro Por uma vida melhor como prejudicial aos jovens, por veicular uma proposta populista que sonega o conhecimento verdadeiro e ignora normas e convenções sociais. Em relação a esse campo, não podemos deixar de destacar o trocadilho entre "demagogia do oprimido" e "Pedagogia do Oprimido", nome de uma das obras mais conhecidas do filósofo e educador Paulo Freire, cujo tema central é a educação emancipatória das classes populares. Certamente, ao se decalcar da "Pedagogia do Oprimido" a "demagogia do oprimido", desliza-se do sentido de popular (sentido positivo) para o de populista (sentido negativo), e faz-se, nesse caso, uma particitação em forma de alusão. Termos como "crime" e "assassinato" significam a proposta como uma infração à Lei, remetendo-a ao campo da justiça. Os demais termos, "desastre", "gramaticofobia", "lixo acadêmico" e "visão mesquinha", originários de campos conceituais variados, também se apresentam como recursos semântico-lexicais para a execração do Outro.

Esse processo de tradução-simulacro do DM realizado pelo DU se espraia pelo corpo todo das matérias aqui examinadas, como podemos constatar pelas Sequências Discursivas (SD) a seguir:

SD1. Adotado nas aulas de português de meio milhão de estudantes do ensino fundamental, o livro Por uma Vida Melhor é uma amostra do que propaga esse círculo de falsos intelectuais. Escreve Heloisa Ramos, uma das autoras: "Você pode estar se perguntando: 'Mas eu posso falar os livro?'. 'Claro que pode"'. O erro crasso de 
concordância seria apenas uma "variação popular", segundo a autora. (Renata Betti e Roberta de Abreu Lima, Veja, Edição 2218, 25/05/11, destaque nosso).

$\mathrm{Na} \mathrm{SD} 1$, podemos observar que é com base no livro virtual construído pelos enunciados aforizados que os enunciadores-jornalistas citam em sua matéria o par adjacente pergunta-resposta - "Mas eu posso falar os livro?" "Claro que pode" - que, no texto fonte, faz parte de uma cenografia de diálogo professor-aluno em sala de aula. Sem levar em conta o contexto e o cotexto em que essa cenografia se insere, os enunciadoresjornalistas, partindo do pré-construído de que há apenas um português correto, interpretam a forma 'os livro' como 'erro crasso de concordância' e colocam sob suspeição a leitura dessa construção como "variação popular". Nessa SD, as aspas configuram um caso típico de modalização autonímica, distinguindo-se da pura autonímia como uma forma de o enunciador mostrar que está duplicando suas palavras - como uso pelo seu "próprio" discurso e como menção a um discurso Outro. As palavras aspeadas constituem um corpo estranho, deslocado, fora de lugar, mantido à distância, não-amalgamado ao fio discursivo, implicando, assim, uma dissensão do enunciador, uma atitude metalinguística que o leva a desdobrar-se em dono e juiz das palavras. Conforme Authier-Revuz (2004), a fala entre aspas é uma fala vigiada, controlada, "mantida"3 e não uma fala abandonada a si mesma, aceita sem reservas. Na SD1, as aspas que sinalizam a citação na forma de discurso direto indiciam uma nãocoincidência de locutores; já as aspas que demarcam a expressão "variação popular" indiciam uma não coincidência de posições enunciativas entre o DU que lê 'os livro' como 'erro crasso de concordância' e o DM que o lê como 'variação linguística'. Essas aspas funcionam, pois, como uma espécie de barreira para separar dois discursos antagônicos, impedindo-os de se misturar e se tornar indistintos, além de desacreditar o princípio fundamental do DU.

\footnotetext{
${ }^{3}$ O sentido de "manter" é aqui equivalente ao de "manter seu cachorro, seus empregados, sua casa” (AUTHIER-REVUZ, 2004, p. 219).
} 
Em SD2, SD3 e SD4, a seguir, mais tradução-simulacro da tese sociolinguística, segundo o idioma do DU, pode ser observada:

SD2. "Uma coisa é compreender a evolução da língua, que é um organismo vivo, a outra é validar erros grosseiros", diz Marcos Vilaça, presidente da Academia Brasileira de Letras. "É como ensinar tabuada errada. Quatro vezes três é sempre 12, na periferia ou no palácio." (Amauri Segalla e Bruna Cavalcanti, ISTO É, Edição 2167, 20/05/11, destaque nosso)

$\mathrm{Na}$ SD2, a gramática é comparada à tabuada, tão invariável e tão precisa quanto ela. Ensinar que se pode dizer 'os livro' é "como ensinar tabuada errada. Quatro vezes três é sempre 12, na periferia ou no palácio”. Quer dizer, assim como a tabuada, a norma gramatical não deve variar em função do contexto. Segundo essa lógica, não se pode falar em norma popular (da periferia) e norma culta (do palácio). Essa identificação entre norma gramatical e tabuada que legitima a classificação de 'os livro' como 'erro grosseiro', é insustentável no universo semântico do DM, que já tem como definitiva a incomensurabilidade entre as línguas naturais e as formais, aliás, o tendão de Aquiles da lógica e da filosofia da ciência.

SD3. A fessora dice também que escreveu desse jeito para subestituir a nossão de "certo e errado" pela de "adequado e inadequado". Vai ver que quis livrar a cara do Lula que agora vive dando palestas e fala muita coisa inadequada. Só que a Gramática eziste para encinar agente como falar e escrever corretamente no idioma portugues. $A$ Gramática é uma espéce de Constituissão do edioma pátrio e para ela não existe essa coisa de adequado e inadequado. Ou você segue direitinho a Constituição ou você está fora da lei - como se diz? magna. Diante do pobrema um acessor do Minestério declarou que "o ministro Fernando Adade não faz análise dos livros didáticos". (...) (Carlos Eduardo Novaes, Jornal do Brasil, 16/05/11, destaque nosso)

$\mathrm{Na}$ SD3, cujo enunciador pretende desqualificar e zombar do livro didático escrevendo como analfabeto, na eterna confusão entre normas linguísticas e convenções ortográficas reinante no senso comum, a gramática é igualada à Constituição: “A Gramática é uma espéce de 
Constituissão do edioma pátrio e para ela não existe essa coisa de adequado e inadequado. Ou você segue direitinho a Constituição ou você está fora da lei - como se diz? - magna.”. Quem não segue a Gramática, como quem não segue a Constituição, é um fora da lei, um bandido, ou seja, é um infrator. Essa leitura que projeta sobre a gramática os semas da Constituição é reforçada pela afirmação de que "a Gramática [...] é a dona da verdade", de que é ela "quem dis o que está certo", e, de que "o Minestério que é da Educassão deve ser o primeiro a respeitar" a Gramática, com "G" maiúsculo, já que ela tem o estatuto de Lei, e, como tal é um nome próprio e não um nome comum. Assim, como a Constituição é a carta magna, a lei maior, o conjunto dos preceitos e regras que regem a vida de uma nação, definindo o que é legal, a Gramática é a carta magna que rege os usos da língua, definindo o que é certo (legal) falar e o que é errado (ilegal).

SD4. Não, leitor, o título acima (Inguinorança) não está errado, segundo os padrões educacionais agora adotados pelo mal chamado Ministério de Educação. Você deve ter visto que o MEC deu aval a um livro que se diz didático no qual se ensina que falar "os livro" pode. (...) Os autores do livro criminoso poderiam usar outro exemplo: "Posso matar um desafeto? Claro que pode. Mas fique atento porque, dependendo da situação, você corre o risco de ser vítima de preconceito jurídico". Tal como matar alguém viola uma norma, matar o idioma viola outra. Condenar uma e outra violação está longe de ser preconceito. É um critério civilizatório. (Clóvis Rossi, Folha de São Paulo, 15/05/11, destaque nosso).

Na SD4, é ao universo semântico do direito penal que o enunciador recorre para traduzir a tese defendida pelo livro didático ("livro criminoso") como infratora do código gramatical que autoriza apenas uma conduta social ao falante de português, ou seja, dizer 'os livros'. Tendo como pano de fundo esse universo legal, o enunciador apela para o absurdo, encenando um diálogo que poderia ser dito pelos autores-enunciadores do livro didático no lugar daquele que eles encenam: "Mas eu posso falar 'os livro?' Claro que pode. Mas fique atento porque, dependendo da situação, você corre o risco de ser vítima de preconceito lingüístico" (Livro didático) 
(destaque nosso) "Posso matar um desafeto? Claro que pode. Mas fique atento porque, dependendo da situação, você corre o risco de ser vítima de preconceito jurídico" (Clóvis Rossi, Folha de S. Paulo,15/05/11, destaque nosso)

Essa dobra de um enunciado sobre o outro, emparelhando "falar 'os livro""/"matar um desafeto" e "preconceito linguístico"//preconceito jurídico", no tocante à violação das normas, é a quintessência do DU, uma espécie de fundamentalismo gramatical, defendido com a veemência de quem se imagina o baluarte da Verdade, da Lei e da Norma Linguística: "Tal como matar alguém viola uma norma, matar o idioma viola outra. Condenar uma e outra violação está longe de ser preconceito. É um critério civilizatório". Por pouco, os infratores do código gramatical, os assassinos do idioma, se livram das grades! Aliás, não faltou quem sugerisse a censura da obra, quer pela sua retirada de circulação, quer pela recomendação estapafúrdia de fazê-la circular com uma errata (Errata para corrigir posicionamento ideológico, quem já viu?! Nos tempos da ditadura, as ideias julgadas contrárias ao regime eram caladas por tarjas pretas.). Em resumo, metaforizada como 'tabuada', como 'Constituição' e como 'Código Penal', a gramática se patenteia como aquela que diz a Norma a ser respeitada e seguida por todos os falantes em qualquer situação. $\mathrm{O}$ enunciador que fala na SD4 não foi o único a dizer que quem desobedece à regra de concordância verbal "mata o idioma"; com palavras diferentes, outros disseram: "o livro assassina a língua portuguesa" (Amauri Segalla e Bruna Cavalcanti, ISTO É, Edição 2167, 20/05/11); “por se pensarem sábios, [os doutores] destroem a língua que os grandes escritores construíram" e "Enquanto os épicos enriqueceram e cristalizaram os idiomas, o MEC quer deletá-la, no sentido etimológico do verbo, em latim!" (José Fernandes, O Popular, 20/05/11).

Muitas matérias que circularam na mídia vincularam a tese de que "toda língua é conjunto de variedades" ao Presidente Lula e ao governo petista, apesar de ela estar em circulação no campo da linguística desde o final da década de 1960 e no campo do ensino de língua materna desde a década de 1980. Na SD3, a substituição do critério de avaliação certo/errado por adequado/inadequado em relação ao contexto é vista como 
um ato de condescendência à fala do presidente que uma vez mais é feita alvo de escárnio pela mídia: "Vai ver que quis livrar a cara do Lula que agora vive dando palestras e fala muita coisa inadequada" (Carlos Eduardo Novaes, Jornal do Brasil, 16/05/11). Na SD5 e SD6, avistam-se outras associações do caso do livro didático com a fala do Presidente:

SD5. Na verdade, o governo está implantando no país um novo método pedagógico e revolucionário: a Demagogia do Oprimido. O MEC (Ministério dos Erros de Concordância) não vai parar por aí: $o$ ministro Fernando Errahd vai tornar obrigatória a introdução no currículo escolar do idioma sindical, a Língua Presa. Essa grande virada na educação brasileira começou com o presidente Luís Sintáxio Lula da Silva que nunca acertou uma concordância na vida. (Agamaneon Mendes Pedreira, O Globo, 22/05/11, destaque nosso).

SD6. Ciência petista. Após a publicação na imprensa do livro aprovado pelo MEC ensinando o molusquês (que angariou a bagatela de $\mathrm{R} \$ 700$ mil para a autora operária e $\mathrm{R} \$ 5$ milhões para a editora, num país famoso por sua incultura), que muitos afirmaram ser mais uma obra do petismo barbarizando o país [...] (Flávio Morgenstern, www.implicante.org, 19/05/11, destaque nosso).

Na SD5, em tom derrisório, de escracho mesmo, a variante popular é metaforizada como "o idioma sindical, a Língua Presa", numa alusão à fala ciciada do Presidente Luís Inácio Lula da Silva ("Luís Sintáxio Lula da Silva") "que nunca acertou uma concordância na vida". Na SD6, o caso é nominado como 'ciência petista' e a língua ensinada pelo livro chancelado pelo MEC, como "molusquês", quer dizer, uma língua primitiva como primitivo é o filo mollusca (do latim mollis = mole), pois, no tempo em que ainda não havia vida no ambiente terrestre, os moluscos já habitavam os mares. Quando os peixes surgiram nos oceanos, os moluscos já existiam há milhares de anos. A aprovação de tal livro pelo MEC é traduzida como "mais uma obra do PT barbarizando o país". Enfim, o que o enunciador chama ironicamente de 'ciência petista' é a ciência do atraso cultural, já que tanto "molusquês" quanto "barbarizar" possuem o sema [- evoluído], renegado pelo discurso iluminista, que, como já vimos, alimenta o DU. Em nome do iluminismo, também foi dito que "a obra vai condenar esses 
jovens a uma escuridão cultural sem precedente" (Amauri Segalla e Bruna Cavalcanti, ISTO É, Edição 2167, 20/05/11); a uma volta "ao sistema tribal (onde) cada um fala como quer" (José Sarney, Folha de S. Paulo, 20/05/11). Ainda sob o império do discurso iluminista, deparamo-nos, na SD7, com a tradução-simulacro de 'Ministério da Educação' como "Ministéro da Inducação", cuja palavra 'Inducação' traz o prefixo In, significando 'não', ou seja, o Ministério que adota a linguagem do povão (metonimicamente representada pela cacografia) se tornará o "Ministério da Não-educação", principalmente para aqueles enunciadores que ainda reivindicam o retorno do latim às salas de aula da escola básica como condição para se falar-escrever corretamente o português: "Miserere nobis, Domine!"

SD7. Infelizmente, por se pensarem sábios, destroem a língua que os grandes escritores construíram. Certamente, Camões, Fernando Pessoa, Machado de Assis, Drummond estão remexendo nos túmulos! (...) Enquanto os épicos enriqueceram e cristalizaram os idiomas, o MEC quer deletá-la, no sentido etimológico do verbo, em latim! Se ele (MEC) insistir nessa aberração, certamente mudará de nome, pois adotará a linguagem do povão e se tornará "Ministéro da Inducação"! Miserere nobis, Domine! (José Fernandes, O Popular, 20/05/11, destaque nosso)

Outros simulacros para o nome Ministério de Educação e Cultura "Ministério dos Erros de Concordância" (SD5), "Minestério da Educassão" (SD3) e "o mal chamado Ministério de Educação" (SD4) - persistem na produção de sentidos que desmoralizam o Outro, o que nos faz recorrer a Maingueneau (2005, p. 114), ao dizer que "polemizar é, sobretudo, apanhar publicamente em erro, colocar o adversário em situação de infração em relação a uma Lei que se impõe como incontestável."

\section{A TÍTULO DE CONCLUSÃO...}

Os textos cujos recortes foram aqui analisados constituem a ínfima parte de um arquivo abundante em matérias midiáticas produzidas com base nos enunciados destacados e aforizados do livro didático Por uma vida 
melhor, predominantemente pautadas pela grade semântica do DU. Embora as leituras enviesadas tenham cadenciado o debate, algumas raras vozes da mídia se posicionaram criticamente em relação à cobertura tendenciosa do caso pela imprensa brasileira. Lembramos aqui a matéria "Jornalistas com déficit de letramento", assinada por Weden e publicada no blog de Luis Nassif, aberta com um ditado popular muito apropriado ao que foi visto e ouvido nas semanas em que o livro didático foi fato noticioso na mídia: "[...] médicos enterram seus erros. E os jornalistas os repercutem". Essa matéria, além de apontar 'a ignorância científica', 'a leviandade intelectual', 'o oportunismo político' e 'os interesses mercadológicos', destaca o déficit de letramento dos jornalistas, evidenciado pela 'dificuldade de relacionar textos', 'desatenção ao cotexto em que aparecem as sentenças' e 'incapacidade de associar o texto ao contexto de enunciação'. O jornalista vai longe na crítica ao que chama de "um novo crime da imprensa", fornecendo uma lista com nomes de colegas de profissão e de outras figuras notáveis que devem ter "a humildade de consultar o capítulo, antes de emitir novas opiniões" sobre o livro, assim como apresentar um pedido de desculpa àqueles que foram caluniados. Nessa matéria parece ecoar a opinião da sociolinguista brasileira Marta Scherre, para quem a mídia brasileira, no que se refere às questões linguísticas, "tem rompido com a ética jornalística, que é acima de tudo, formar opinião com fatos e não com distorção dos fatos” (2002, p. 218).

Neste estudo, buscamos, detendo-nos no caso do livro didático, refletir sobre uma característica do funcionamento da mídia contemporânea, aqui definida como uma máquina de destacar, aforizar e fazer circular os enunciados, culminando com a produção pletórica de simulacros, que patenteiam a força do DU. Afinal, como afirma Maingueneau (2005, p. 119), “A 'vida' de um discurso, a geração de enunciados inéditos que fazem Norma-Padrão parte de seu sistema de restrições é, pois, o fato de ser considerado o Todo da verdade de um campo por uma comunidade de crentes". Em se tratando do discurso da mídia brasileira, a principal fiadora e mantenedora do DU, a Lenda, a Verdade, é que "o português é a " - único, homogêneo, invariável e a ser conservado para sempre. No avesso de tais semas positivos estão os 
negativos - plural, heterogêneo, variável e em eterno devir - que representam uma ameaça à conservação e à vida da língua. Os semas negativos do DU são, na verdade, os semas positivos do DM, cujo princípio nuclear é o de que "o português é uma pluralidade de normas". Assim, quando a mídia se pronuncia sobre o livro didático, fiador do DM, ela introduz o Outro no intradiscurso na forma de simulacro, traduzindo-o segundo as restrições semânticas do DU. Como já mostramos anteriormente, o próprio processo de destacar e aforizar os enunciados constitui um simulacro, na medida em que apaga aquilo que poderia colocar sob suspeita a interpretação que um faz do Outro. O destaque e a aforização constituem, desse modo, um simulacro-primeiro com potencial para fazer proliferar copiosamente na mídia outros simulacros. No "jogo discursivo", um discurso não interpreta a si mesmo, pois o trabalho de interpretação cabe ao exterior, é reservado para o Outro. Destarte, a interincompreensão é inalienável da interpretação, o que nos leva a pensar na propriedade do ditado popular "Tradutores, traidores". Se esse ditado é apropriado para sintetizar o que ocorre quando traduzimos de uma língua para outra, ele é mais do que apropriado para descrever o que se passa quando traduzimos de um discurso para outro.

O que aqui dissemos sobre o destaque, a aforização, a produção e a circulação de simulacros em relação a esse acontecimento discursivo representa os primeiros tateios de um corpus volumoso que pede ainda para ser "trabalhado, relido, ruminado, revisitado, no tempo, no silêncio, com paciência. Para ver as coisas, é preciso olhar muitas vezes." (KRIEGPLANQUE, 2009, p. 26).

\section{REFERÊNCIAS}

AGUIAR, C. A. et alii. Por uma vida melhor. Coleção "Viver, Aprender". Volume 2/Multidisciplinar. São Paulo: Editora Global, 2011.

AUTHIER-REVUZ, J. Entre a transparência e a opacidade: um estudo enunciativo do sentido. Porto Alegre: EDIPUCRS, 2004.

FREIRE, p. Pedagogia do oprimido. Rio de Janeiro: Paz e Terra, 1974. 
KRIEG-PLANQUE, A. Entrevista com Alice Krieg-Planque (Céditec, Université Paris XII) por Philippe Schepens, traduzida por Luciana Salazar Salgado e Sírio Possenti. Linguasagem, 6. edição, 2009. Disponível em:

$<$ www.letras.ufscar.br/linguasagem/edicao06/entrevista.php>.

MAINGUENEAU, D. Les phrases sans texte. Paris: Armand Colin, 2012.

. A aforização proverbial e o feminino. In: MOTTA, A. R.; SALGADO, L.

S. Fórmulas discursivas. São Paulo: Contexto, 2011.

. Aforização: enunciados sem texto? Tradução de Ana Raquel Motta. In:

MAINGUENEAU, D. Doze conceitos em Análise do Discurso. Org. Sírio Possenti e Maria Cecília Pérez de Souza-e-Silva. São Paulo: Parábola Editorial, 2010.

. Citação e destacabilidade. Tradução de Roberto Leiser Baronas e Fábio César Montanheiro. In: MAINGUENEAU, D. Cenas da enunciação. Org. Sírio Possenti e Maria Cecília Pérez de Souza-e-Silva. São Paulo: Parábola Editorial, 2008.

. Les énoncés détachés dans la presse écrite. De la surassertion à

l'aphorisation. TRANEL. Travaux Neuchâtelois de linguistique. Neuchâtel, n. 44, p. 107-120, 2006.

. Gênese dos discursos. Curitiba: Criar, 2005.

MOTTA, A. R.; SALGADO, L. S. Fórmulas discursivas. São Paulo: Contexto, 2011.

REY, A. Usos, julgamentos e prescrições lingüísticas. In: Marcos Bagno (org.). Norma Lingüistica. São Paulo: Edições Loyola, 2002, p. 115-144.

SCHERRE, M. A Norma do Imperativo e o Imperativo da Norma: uma reflexão sociolingüística sobre o conceito de erro. In: BAGNO, M. (Org.). Lingüística da norma. São Paulo: Edições Loyola, 2002. p. 217-251.

Recebido em: 18/09/12. Aprovado em: 30/04/13.

Title: For a better life in the media: discourse, aphorization and controversy

Authors: Roberto Leiser Baronas; Maria Inês Pagliarini Cox Abstract: In this article, from the perspective of discourse analysis, the authors study the controversy that took place in the media regarding the Portuguese language school textbook Por uma vida melhor [For a better life] in the first semester of 2011, which generated a large file of journalistic material about the topic. The controversy was established from a set of statements detached from a chapter of the book and modified according to the Standard Portuguese only ideology supported by the Globo Media 
Companies. The discursive corpus, consisting of statements detached from the journalistic material on the theme that circulated as printed material and/or in the Internet, was examined based on the concepts of detachability and aphorization (MAINGUENEAU, 2010, 2008) as well as polemics, intercomprehension, translation and simulacrum (MAINGUENEAU, 2010). It is examined whether detachability and aphorization enhance the production and circulation of simulacra in the media sphere.

Keywords: Media discourse. Detachability. Aphorization. Polemics. Simulacrum.

Título: Por una vida mejor en los medios: discurso, aforización y polémica

Autores: Roberto Leiser Baronas; Maria Inês Pagliarini Cox

Resumen: En este artículo se estudia, en la perspectiva del análisis de discurso, la polémica en torno del libro didáctico de lengua portuguesa Por una vida mejor, que tuvo lugar en los medios en el primer semestre de 2011, generando un numeroso archivo de materias periodísticas sobre el tema. La polémica se instauró a partir de un conjunto de enunciados destacados del capítulo del libro, modificados según la ideología del portugués único de las Organizaciones Globo. El corpus discursivo, constituido de enunciados recortados de materias sobre el tema que circularon de modo impreso y/o por la internet, fue examinado con base en los conceptos de destacabilidad y aforización (MAINGUENEAU, 2010, 2008), bien como en los conceptos de polémica, interincomprensión, traducción y simulacro (MAINGUENEAU, 2005). Se verifica si el destaque y la aforización potencializan la producción y la circulación de simulacros en la esfera mediática.

Palabras-clave: Discurso mediático. Destacabilidad. Aforización. Polémica. Simulacro. 